2016

\title{
Conservatives, the Supreme Court, and the Constitution: Judicial-Government Relations, 2006-15
}

Christopher P. Manfredi

McGill University, christopher.manfredi@mcgill.ca

Follow this and additional works at: http:// digitalcommons.osgoode.yorku.ca/olsrps

Part of the Law and Politics Commons

\section{Recommended Citation}

Manfredi, Christopher P., "Conservatives, the Supreme Court, and the Constitution: Judicial-Government Relations, 2006-15" (2016). Osgoode Legal Studies Research Paper Series. 166.

http://digitalcommons.osgoode.yorku.ca/olsrps/166 


\section{OSGOODE HALL LAW SCHOOL \\ LEGAL STUDIES RESEARCH PAPER SERIES}

Research Paper No. 32

Volume 12, Issue 7, 2016

\section{Conservatives, the Supreme Court, and the Constitution: Judicial-Government Relations, 2006-15 Osgoode Hall Law Journal, Vol. 52(3), 2015, Forthcoming.}

\section{Christopher Manfredi}

This paper can be downloaded free of charge from: http://ssrn.com/abstract=2715091

Further information and a collection of publications from the Osgoode Hall Law School Legal Studies Research Paper Series can be found at:

http://www.ssrn.com/link/Osgoode-Hall-LEG.html

\section{Editors:}

Editor-in-Chief: Carys J. Craig (Associate Dean of Research \& Institutional Relations and Associate Professor, Osgoode Hall Law School, York University, Toronto)

Production Editor: Kiana Blake (Osgoode Hall Law School, York University, Toronto) 
Osgoode Legal Studies Research Paper No. 32

Vol. 12/ Issue. 7/ (2016)

\title{
Conservatives, the Supreme Court, and the Constitution: Judicial- Government Relations, 2006-15 \\ Osgoode Hall Law Journal, Vol. 52(3), 2015, Forthcoming. \\ Christopher Manfredi
}

\begin{abstract}
:
Three high profile government losses in the Supreme Court in late 2013 and early 2014, combined with the government's response to those losses, generated a narrative of an especially fractious relationship between the Conservative government of Prime Minister Stephen Harper and the Court. This article analyzes this narrative more rigorously by going beyond a mere tallying of government wins and losses in the Court. Specifically, it examines Charter-based invalidations of federal legislation since 2006, three critical reference opinions rendered at the government's own request, and two key judgments delivered in the spring of 2015 concerning aboriginal rights and the elimination of the long-gun registry. The article argues that the relationship between the Conservative government and the Court from 2006 to 2015 was much more complicated than the "fractious relationship" narrative would suggest. However, the Conservative government did adopt a more consistently confrontational approach in its legislative responses than its predecessors.

\section{Keywords:}

Conservatism, Constitution, Supreme Court, Canada, Beverley McLachlin, Stephen Harper

\section{Author(s):}

Christopher Manfredi

McGill University

E: christopher.manfredi@mcgill.ca
\end{abstract}




\title{
Conservatives, the Supreme Court, and the Constitution: Judicial- \\ Government Relations, 2006-15
}

\author{
Christopher Manfredi
}

On December 20, 2013, the Supreme Court of Canada unanimously declared three key sections of the Criminal Code that regulate prostitution unconstitutional under s.7 of the Charter of Rights and Freedoms. ${ }^{1}$ Three months later, on March 21, 2014, the Court declared that the government's nomination of a federal court judge (Justice Marc Nadon) to fill a Quebec vacancy on the Court violated the Supreme Court Act, and that amending the Act to change the Court's composition could only be achieved through constitutional amendment. ${ }^{2}$ Just over a month after that judgment, the Court rejected the government's proposed legislation for reforming the term of Senators and the manner in which they are appointed. ${ }^{3}$ These three high profile government losses in the Supreme Court generated a growing narrative of an especially fractious relationship between the Conservative government of Prime Minister Stephen Harper and the Supreme Court.

The origins of the narrative can probably be traced to 2011, but it reached a crescendo in 2014 and 2015. Writing in the Globe and Mail in 2014, Lawrence Martin described the Court as having become, not by design but in effect, "the Official Opposition in Ottawa." 4 Similarly, Vanessa Naughton described a "contentious relationship," beset by "flare-ups between the Harper government and the top court...that have put a wrench in the Conservative government's plans." 5 The narrative continued

\footnotetext{
1. Canada (Attorney General) v. Bedford [2013] 3 S.C.R 1101.

2. Reference re Supreme Court Act, ss. 5 and 62014 SCC 21 (2014-03-21). The judgment effectively entrenched the Supreme Court Act in the Constitution.

${ }_{3}$. Reference re Senate Reform 2014 SCC 32 (2014-04-25).

4 . Lawrence Martin, "The Supreme Court is Harper's Real Opposition,"

http://www.theglobeandmail.com/globe-debate/the-supreme-court-is-harpers-realopposition/article19395285/ (accessed 20 February 2015).

5 . Vanessa Naughton, "Harper vs. the Supreme Court of Canada," http:/globalnews.ca/news/1325937/harper-vs-the-supreme-court-of-canada/ (accessed 20
} February 2015). 
into 2015. As Tristin Hopper wrote in the National Post: "In one of the starkest examples in Canadian history of two branches of government turning against one another, the redrobed members of the Supreme Court of Canada have spent months systematically shooting down virtually every issue the Conservatives hold dear." ${ }^{\circ}$ Hopper's National Post colleague, Joseph Brean, made a similar point five weeks later, suggesting that a series of losses "has solidified an image of the court as the government's nemesis, with McLachlin as its fearless, indomitable leader." "7 As Osgoode Hall Law Dean Lorne Sossin wrote in The Walrus, rulings against the federal government "have become stylized as Harper v. the Court.",

The government's own reaction to some of these losses added plausibility to the narrative and suggested that any animosity might be mutual. A few days after the Court's rejection of his Senate reform plan, showing his frustration with the Court's judgments during the previous few months, the Prime Minister suggested that the Chief Justice had acted improperly by having attempted to contact him about the Nadon appointment. ${ }^{9}$ The Prime Minister's remarks, and the Chief Justice's public response, were unprecedented in Canadian executive-judicial relations. ${ }^{10}$ The government responded to its loss in the prostitution case by proposing Bill C-36, which retains the invalidated Criminal Code

6 . Tristin Hopper, "A Scorecard of the Harper government's wins and losses at the Supreme Court of Canada," National Post (April 15, 2015). See http://news.nationalpost.com/news/canada/scoc-harper-gov-scorecard-741324 (accessed 31 July 2015).

7. Joseph Brean, "'Conscious objectivity': That's how the chief justice defines the top court's role. Harper might beg to differ," National Post (May 23, 2015). See http://news.nationalpost.com/news/conscious-objectivity-thats-how-the-chief-justicedefines-the-top-courts-role-harper-might-beg-to-differ (accessed 31 July 2015).

8 . Lorne Sossin, “Court Dismissed, The Walrus (January/February 2015). See http://thewalrus.ca/court-dismissed/ (accessed 2 August 2015).

9 . This was in stark contrast to his initial measured reaction to the Nadon ruling on March $25^{\text {th }}$, in which he stated that the government would respect both the letter and sprit of the decision. See http://www.theglobeandmail.com/news/politics/harper-says-he-willrespect-supreme-courts-blocking-of-nadon/article17661060/ (accessed 11 August 2014).

10. Supreme Court of Canada, News Release, 2 May 2014. 
provisions with some amendments, but also establishes two new criminal offences related to prostitution. ${ }^{11}$ Similarly, it responded to an earlier loss concerning safe intravenous drug injection sites with Bill C-2, which would amend s. 56 of the Controlled Drugs and Substances Act to require extensive submissions by provincial, local, and law enforcement authorities, among others, before the Minister could grant an exemption. ${ }^{12}$

The purpose of this article is to analyze this narrative more rigorously by going beyond a mere tallying of government wins and losses in the Court. Indeed, two features of constitutional litigation make the relationship between a government and the Supreme Court more difficult to determine than it might otherwise appear. First, with the notable exception of reference cases-where a government explicitly seeks a constitutional opinion from the Court-and some federalism cases - where one government directly challenges the actions of another-governments are usually involuntary participants in constitutional litigation. This is particularly true in cases involving the Charter of Rights and Freedoms, where governments are forced to defend legislative and executive action against challenges from individuals and groups. Second, governments often find themselves defending legislation enacted by previous governments. Of course, governments may not always view this negatively: they may disagree with the statute under review, whatever its provenance, and thus welcome judicial intervention against it. Nevertheless, the fact that governments are often parties to disputes over legislation or policies for which they are not responsible makes case outcomes a poor measure of government-judicial relations.

The article presents its analysis in three main parts. First, it examines Charterbased invalidations of federal legislation by the Supreme Court since 2006. Second, it

11. For a good summary and analysis of Bill C-36, see http://www.parl.gc.ca/About/Parliament/LegislativeSummaries/bills 1s.asp?Language=E $\& 1 \mathrm{~s}=\mathrm{c} 36 \&$ Parl $=41 \&$ Ses $=2 \&$ source=library prb (accessed 2 March 2015).

12. This case was Canada (Attorney General) v. PHS Community Services [2011] 3 S.C.R. 134, which is discussed at length below. 
examines three critical reference opinions rendered by the Court at the government's own request, each of which delivered a result contrary to the government's wishes. Third, the article examines two key judgments delivered in the spring of 2015 concerning aboriginal rights and the elimination of the long-gun registry.

\section{The Conservatives, the Supreme Court, and the Charter}

The relationship between Canadian conservatism and the Charter of Rights and Freedoms has always been ambivalent. On the one hand, conservatives were among the most vocal, if not sole, opponents of adopting the Charter, and conservative scholars have been strong critics of the Charter and its judicial application. ${ }^{13}$ On the other hand, conservative groups have actively participated in Charter litigation, including as initiators of litigation. ${ }^{14}$ The Reform Party-precursor to the present-day Conservative Partyaccepted the principle of a judicially enforceable Charter in its 1996 policy platform, but advocated a narrower definition of equality rights and the entrenchment of property and contract rights in the Charter. ${ }^{15}$ Indeed, to the extent that conservatism advocates limited government, judicial enforcement of constitutional rights against government overreaching is an important means to that end. Nevertheless, invalidation of federal

13. See F.L. Morton and Rainer Knopff, The Charter Revolution \& the Court Party (Peterborough: Broadview Press, 2000); Ian Brodie, Friends of the Court: The Privileging of Interest Group Litigants in Canada (Albany: State University of New York Press, 2002); Rory Leishman, Against Judicial Activism: The Decline of Freedom and Democracy in Canada (Montreal and Kingston: McGill-Queens University Press, 2006). Some commentators would include me in this group, see Christopher P. Manfredi, Judicial Power and the Charter: Canada and the Paradox of Liberal Constitution, $2 d$ ed. (Don Mills: OUP Canada, 2001).

14. See Dennis R. Hoover, and Kevin R. den Dulk, "Christian Conservatives Go to Court: Religion and Legal Mobilization in the United States and Canada," International Political Science Review 25 (2004): 9-34; Avril Allen, “An Analysis of Interest Group Litigation in Canada," 2007 (Unpublished presentation on file with the author).

15. See its Blue Book: A Fresh Start for Canadians, 1996-97, https://www.poltext.org/sites/poltext.org/files/plateformes/can1996r_plt_en_12072011_1 24840.pdf (accessed 14 August 2014). 
legislation and other policy initiatives by the Supreme Court on Charter grounds during the Harper government is a key element in the development of the "fractious relationship" narrative.

The first step in understanding this aspect of the Conservative government's relationship to the Supreme Court under the Charter is to step back and look at the relationship between the Court and all post-Charter governments. The post-Charter era has been one of remarkably low turnover among governments in Canada. Indeed, there have only been three federal governments during this period: the Progressive Conservative government (1984-1993, hereafter PC), the Liberal government (1993-2006, hereafter LIB2), and the Conservative Party government (2006-current, hereafter CPC). The Charter litigation experience of these governments before the Supreme Court illustrates the point made above that governments often find themselves engaged in litigation over a previous government's actions. As of 31 July 2015, these three governments were on the losing side in 51 cases in which the Court declared legislation (or other government action) unconstitutional under the Charter. ${ }^{16}$ However, only six of those cases involved losses involving their own legislation. For example, although the PC government found itself on the losing side in 22 Charter cases, 21 of those losses came in cases defending legislation enacted by previous governments, including the Liberal government of Pierre Trudeau (1968-79, 1980-84, hereafter LIB1). Similarly, of the LIB2 government's seventeen Charter losses, fifteen involved legislation passed by previous governments. Finally, eight of the eleven CPC government's losses in Charter litigation have involved legislation enacted by predecessor governments.

The frequency with which the Harper government has had its legislation invalidated by the Court on Charter grounds ( 0.33 per year in office) compares quite favourably to its two predecessor governments (1.00 for the PC government and 0.38 for

16. This figure includes all invalidations from 1984 until July 2015. 
the LIB2 government). Moreover, the rate at which it has lost Charter cases as the defending government is lowest of the three governments to date (1.22 compared to 2.56 and 1.31). However, the CPC government's April 2015 loss with respect to mandatory minimum sentences for firearms violations raised both its number and rate of loss as both enactor and defender above that of its two predecessor governments.

Table 1

Invalidations by Enacting and Defending Government

\begin{tabular}{|l|l|l|l|l|l|l|l|}
\hline Government & $\begin{array}{l}\text { Period in } \\
\text { Office }\end{array}$ & $\begin{array}{l}\text { Invalidated } \\
\text { as Enactor }\end{array}$ & $\begin{array}{l}\text { Rate per } \\
\text { year in } \\
\text { office }\end{array}$ & $\begin{array}{l}\text { Invalidated } \\
\text { as Defender }\end{array}$ & $\begin{array}{l}\text { Rate per } \\
\text { year in in } \\
\text { office }\end{array}$ & $\begin{array}{l}\text { Invalidated } \\
\text { as Enactor } \\
\text { and } \\
\text { Defender }\end{array}$ & $\begin{array}{l}\text { Rate } \\
\text { per } \\
\text { year in } \\
\text { office }\end{array}$ \\
\hline LIB1 & $\begin{array}{l}1968-79, \\
1980-84\end{array}$ & 12 & 0.80 & 1 & 0.07 & 0 & 0.00 \\
\hline PC & $1984-93$ & 9 & 1.00 & 22 & 2.56 & 1 & 0.11 \\
\hline LIB2 & $1993-2006$ & 5 & 0.38 & 17 & 1.31 & 2 & 0.15 \\
\hline CPC & $2006-$ & 3 & 0.33 & 11 & 1.22 & 3 & 0.33 \\
\hline
\end{tabular}

Invalidations of LIB1 legislation under the PC government included important and high profile legislation involving refugee determination proceedings (Singh), abortion regulation (Morgentaler), sexual assault (Seaboyer), and employment insurance (Schachter). ${ }^{17}$ Although the PC government did not precipitate these legal conflicts, it had to defend the legislation and deal with the political and policy impact of the invalidations. The LIB1 statutes invalidated under the LIB2 government were less high profile, although one case involved rules governing the acquisition of citizenship (Benner). ${ }^{18}$ The PC government had five legislative provisions invalidated under the LIB2 government, including important legislation involving tobacco advertising and

17. Re Singh and Minister of Employment and Immigration, [1985] 1 S.C.R. 177; R. v. Morgentaler, [1988] 1 S.C.R. 30; R. v. Seaboyer, [1991] 2 S.C.R. 577; Schachter v. Canada, [1992] 2 S.C.R. 679.

18. Benner v. Canada, [1997] 1 S.C.R. 358. 
labeling (RJR Macdonald) and inmate voting rights (Sauvé). ${ }^{19}$ Each of these instances illustrate the general point suggested by the aggregate data in Table 1: a government's losses in Charter litigation may tell us very little about the relationship between that government and the Court precisely because the loss pertained to legislation enacted by a previous government.

A more detailed examination of the CPC government's experience before the Court in Charter cases indicates that its experience does not differ markedly from that of its predecessor governments. The complicated nature of the Court-government relationship is apparent in Canada (Attorney General) v. Hislop, which is the first judgment in which the Supreme Court invalidated federal legislation after the CPC government came to power. ${ }^{20}$ At issue in Hislop were provisions of the Canada Pension Plan that extended survivorship pensions to same sex partners while simultaneously imposing temporal limits on eligibility for the benefit. In its judgment delivered on March 1, 2007, the Court unanimously held that the temporal eligibility limit infringed the right to equality on the grounds of sexual orientation, and that the infringement could not be saved by s. 1 of the Charter. The Court declared the relevant sections of the Canada Pension Plan Act unconstitutional, thereby extending the benefit to previously ineligible survivors.

At first glance Hislop seems to support the narrative of a Court hostile to the ideological and policy preferences of the CPC government, which-consistent with social conservative elements of its program-defended legislation (unsuccessfully) against an equality rights claim based on sexual orientation. The details of the litigation, however, do not support this simple narrative. First, the provisions challenged in Hislop had been enacted by the LIB2 government in 2000 as part of its legislative response to

19. RJR-MacDonald v. Canada [1995] 3 SCR 199; Sauvé v. Canada (Chief Electoral Officer), [2002] 3 S.C.R. 519. Readers should note that I was an expert for the Government of Canada in Sauvé.

20. Canada (Attorney General) v. Hislop, [2007] 1 S.C.R. 429. 
the Court's judgment in $M v \cdot H .{ }^{21}$ Second, judicial proceedings began during that same government, with the first judicial decision's being rendered in 2003. Third, the decision to appeal the government's losses in the lower courts was also made by the LIB2 government. Only oral argument, held on May 16, 2006, just over three months after the change in government, might be attributed to the CPC government. To be sure, the federal government's position in Hislop was likely consistent with the CPC government's position, but it was not uniquely consistent with that government. The predecessor LIB2 government had enacted the impugned legislation, defended it before lower courts, and been mostly responsible for constructing the case presented to the Supreme Court.

The same dynamic is evident in perhaps the CPC government's highest profile early loss before the Court: Charkaoui v. Canada (Citizenship and Immigration). ${ }^{22}$ Like Hislop, Charkaoui engaged a core issue for the CPC government: national security, especially in the context of anti-terrorism measures. At issue was the constitutionality of procedures under the Immigration and Refugee Protection Act (IRPA) for issuing and determining the reasonableness of security certificates and for reviewing detention under those certificates. A unanimous judgment of the Court, delivered by the Chief Justice, declared that the relevant provisions of the IRPA infringed ss. 7, 9, and 10(c) of the Charter. The Court declared the provisions of no force or effect, but suspended the declaration of invalidity for one year, to give the government an opportunity to revise the legislation. While this result was clearly unwelcome by the CPC government, it cannot be characterized as a repudiation of its policy. The provisions in question had been enacted in 2001 by the Chretien government, and the lower court proceedings began more than a year before the CPC government came to power. As in Hislop, the CPC government became engaged only shortly before oral argument occurred in June 2006.

\footnotetext{
21. M. v. H., [1999] 2 S.C.R. 3.

22. Charkaoui v. Canada (Citizenship and Immigration), [2007] 1 S.C.R. 350.
} 
The related odyssey of Omar Khadr bears similar characteristics. ${ }^{23}$ US forces took Khadr prisoner in Afghanistan in 2002 at the age of 15, transferred him to Guantanamo Bay, and charged him with murder and other terrorism-related charges. In 2003 Canadian officials questioned him at Guantanamo Bay and shared the results of those interviews with US officials. In 2008, following divided judgments by the Federal Court trial and appellate divisions, the Supreme Court held that the Crown had an obligation under s. 7 of the Charter, as interpreted in R. v. Stinchcombe, ${ }^{24}$ to disclose the records of those interviews and the information communicated to US authorities. In 2010 the Court further found that Khadr's Charter rights had been violated by US interrogation techniques in 2003 and 2004, and that he was entitled to a remedy under s. 24(1) of the Charter. However, the Court refused to order the remedy sought by Khadr-an order that Canada request his repatriation from Guantanamo Bay-and instead found that the appropriate remedy was a declaration that Khadr's rights had been violated. The Court left it to the government to determine how best to respond "in light of current information, its responsibility over foreign affairs, and the Charter." Finally, in 2015 the Court delivered an oral judgment from the bench, affirming an Alberta Court of Appeal judgment, that Khadr's sentence for his offences was a youth sentence to be served in a provincial institution.

As in Charkaoui, the Khadr litigation spanned both the LIB2 and CPC governments. Indeed, the constitutional violations identified by the Court in 2008 and 2010 all occurred under the LIB2 government. To be sure, the CPC government took the hardest line possible in the Khadr litigation, and its (non)-response to the Court's 2010 declaration demonstrated its disagreement with how the Court had handled the case. In that sense, the Court's summary dismissal of the CPC government's argument in 2015

23. Canada v. Khadr, [2008] 2 S.C.R. 125; Canada (Prime Minister) v. Khadr, [2010] 1 S.C.R. 44; Bowden Institution v. Khadr, 2015 SCC 26.

24. R. v. Stinchcombe, [1991] 3 S.C.R. 326. 
might be understood as a clear rebuke of the government's position. Thus, while the CPC government was not responsible for the initial violation of Khadr's Charter rights, it failed to mitigate the harm flowing from those violations to the Court's satisfaction.

A similar dynamic is evident in the third judicial invalidation that occurred during the CPC government: R. v. D.B. (2008). ${ }^{25}$ At issue in D.B. were provisions of the Youth Criminal Justice Act (YCJA) enacted by the LIB2 government in 2002 to create a category of "presumptive offences" under which Youth Court judges must impose adult sentences unless the young person demonstrates that a youth sentence would be sufficient to hold him or her accountable for the criminal act. This presumption of an adult sentence for these offences (murder, attempted murder, manslaughter, aggravated sexual assault, and "serious violent offences") reversed the standard procedure in which the Crown bears the onus of showing that the young person has lost the entitlement to a youth sentence. The provisions under review also reversed the onus with respect to publication bans in these cases by requiring youths to demonstrate why they should continue to be protected by the publication ban otherwise required by the YCJA. A five justice majority of the Court held that these provisions infringed the right to liberty protected by $\mathrm{s.7}$ of the Charter in a manner inconsistent with the principles of fundamental justice, and that they could not be justified as a reasonable limit. It therefore rejected the Crown's appeal to set aside the youth sentence. ${ }^{26}$

It should be obvious that the outcome in D.B. was disappointing to the CPC government, but not because it interfered with an element of its own criminal and youth justice policy. The law under review pre-dated the CPC government by four years, the offense that precipitated D.B.'s prosecution occurred three years before the CPC's election, and the trial court judgment occurred two years earlier. The CPC government

25. R. v. D.B. [2008] 2 S.C.R. 3.

26. Interestingly, although the four dissenting justices disagreed with the majority's constitutional reasoning, they nevertheless agreed that the youth sentence was reasonable and should not be interfered with. 
first became involved at the provincial appellate court level, but took clear ownership of the issue by pursuing the appeal to the Supreme Court. In this sense the CPC government was deeply invested in defending the constitutionality of the provisions even if it had not been directly responsible for enacting them. ${ }^{27}$ From this perspective, there is the hint of a conflict between the government and the Court, although the closeness of the judgment does not indicate a sharp conflict. ${ }^{28}$

Two cases decided early in 2015 display similar characteristics. At issue in Canada (Attorney General) v. Federation of Law Societies of Canada (2015) was the constitutionality of provisions of the Proceeds of Crime (Money Laundering) and Terrorist Financing Act as they applied to the legal profession. ${ }^{29}$ First enacted under the LIB2 government, the statute imposes various obligations on "financial intermediaries," including legal professionals, to record and retain information about financial transactions. It also established search and seizure powers, although with limitations with respect to material included within solicitor-client privilege. Although finding the qualified search and seizure provisions rationally connected to a pressing and substantial legislation objective, the Court nevertheless agreed with the Federation of Canadian Law Societies that they were overly restrictive of the s. 8 right against unreasonable search and seizure when applied to the legal profession. The Court thus ordered that the impugned provisions be "read down" to exclude legal professionals from their scope of operation, leaving the statute otherwise intact.

While this judgment might be perceived as another judicial rejection of the CPC government's anti-terrorism policies, that perception would be overbroad. As in D.B.,

27. Although not responsible for enacting the provisions, they were partly the product of political pressure exerted by the CPC's precursors, the Reform Party and Canadian Alliance, when in opposition.

28. Note that Justice Marshall Rothstein, the first — and that point, only-justice appointed by the CPC government joined the dissenting judgment.

29. Canada (Attorney General) v. Federation of Law Societies of Canada, 2015 SCC 7. 
the basic legislative framework originated with another government, and while the CPC government vigorously defended the provisions the judgment cannot be characterized as a direct repudiation of its policy agenda. Moreover, although clearly a governmental loss, Federation of Law Societies of Canada was relatively mild in its invalidation of the statute. The Court accepted the general principle underlying the legislation, and even accepted that its main provisions were legitimately applied to a wide variety of professions. The Court drew the line at the legal profession, and in this sense the judgment might be understood not so much as rejecting a particular policy orientation toward crime prevention, but as protecting the profession of which the Court is an essential component.

Close analysis of another of the government's 2015 losses also fails to support the narrative of high Court-Government hostility. In Mounted Police Association of Ontario v. Canada (Attorney General) (2015) the Court held that excluding RCMP members from the public service labour relations regime and imposing a non-unionized regime on them violated their s. 2 right to freedom of association. ${ }^{30}$ Although the litigation leading to $M P A O$ began shortly after the CPC government's election, the regulations and statutes under review dated back to 1988 and 2003, respectively. Moreover, the judgment was one of two decided in a span of two weeks extending Charter rights to organized labour in novel ways, suggesting that it was not so much directed against the federal government of the day but against a general trend in regulating labour. ${ }^{31}$ In addition, the Court denied a constitutional challenge against wage rollbacks imposed on RCMP members in $2009 .{ }^{32}$ To some degree, the CPC government was an innocent bystander in the Court's reconsideration of its own approach to labour-management relations.

\footnotetext{
30. 2015 SCC 1. Hereafter MPAO.

31. The other case is Saskatchewan Federation of Labour v. Saskatchewan, 2015 SCC 4.

32. Meredith v. Canada (Attorney General) 2015 SCC 2.
} 
One can sense a similar, if more pronounced, dynamic at work in the Court's unanimous judgment in Carter v. Canada (Attorney General) (2015). ${ }^{33}$ In Carter, the Court reconsidered its narrow 1993 decision upholding the constitutionality of the Criminal Code's prohibition against assisted suicide. ${ }^{34}$ The opening paragraphs of this "By The Court" judgment, which is a device often used in deeply controversial cases where the Court wants to put its full institutional weight behind its judgment, are powerful. The Court characterizes the criminal prohibition as condemning "people who are grievously and irremediably ill...to a life of severe and intolerable suffering." Such persons face a cruel choice: "take their own life prematurely, often by violent or dangerous means," or suffer until dying from natural causes. In the Court's view, the question before it was whether a law that forces such a choice violates the rights under s.7 of the Charter to life, liberty and security of the person. The Court recognized the "competing values of great importance" at the heart of this question: "On the one hand stands the autonomy and dignity of a competent adult who seeks death as a response to a grievous and irremediable medical condition. On the other stands the sanctity of life and the need to protect the vulnerable., ${ }^{, 35}$

The Court agreed with the trial judge that the prohibition against assisted suicide violates the s. 7 rights of competent adults. The Court further agreed that, during the two decades since its earlier decision, experiences in other jurisdictions demonstrated that it is possible to design "a properly administered regulatory regime...capable of protecting the vulnerable from abuse or error." ${ }^{36}$ It therefore concluded "that the prohibition on physician-assisted dying is void insofar as it deprives a competent adult of such assistance where (1) the person affected clearly consents to the termination of life; and (2) the person has a grievous and irremediable medical condition (including an illness,

\footnotetext{
33. Carter v. Canada (Attorney General) 2015 SCC 5.

34. Rodriguez v. British Columbia (Attorney General), [1993] 3 S.C.R. 519.

35. 2015 SCC 5, paras. 1, 2 .

36 . Ibid., Carter, para. 3.
} 
disease or disability) that causes enduring suffering that is intolerable to the individual in the circumstances of her condition." ${ }^{37}$ The Court suspended the declaration of invalidity for twelve months to provide Parliament an opportunity to design a regulatory regime that respects individual autonomy and dignity while protecting the vulnerable. ${ }^{38}$

The relationship of Carter to the CPC government is analogous to the relationship of Morgentaler (1988) to the PC government. Both cases involved Criminal Code provisions regulating individuals' control over their own bodies, both sets of provisions engaged competing principles of social morality, neither government was responsible for the policy status quo overturned by the Court, and yet each government inherited the challenge of developing a new policy regime not easily reconcilable with its median ideological position. However, in contrast to Morgentaler (1988), the Carter Court provided some relatively specific guidelines for designing this new regime. The first guideline can be found in the Court's characterization of the Criminal Code provisions as prohibiting "physician-assisted" suicide when those provisions, in fact, established an indictable offence for "everyone who aids or abets a person in committing suicide." Consequently, in voiding this provision, the Court was effectively removing criminal liability from anyone who assists someone to commit suicide. By characterizing its judgment as decriminalizing physician-assisted suicide rather than assisted suicide more generally, the Court signaled that a policy regime in which only physicians may provide assistance would be constitutionally permissible, thereby narrowing the scope of its judgment to some degree.

The other guidelines are more explicit in the Court's reference to (1) competent adults who (2) clearly consent to the termination of life because of (3) a grievous and irremediable medical condition that (4) causes enduring and intolerable suffering. The Court further clarified that individuals could not be required to undertake treatments

37 Ibid., paras. 4, 127.

38 . Ibid., para. 128. 
unacceptable to them. The challenge for the CPC government in response to Carter will be to design a policy regime that includes a process to determine when these conditions have been met. One can envision a policy response in which the invalidated provisions of the Criminal Code remain intact, but with an exemption for physicians where a third party has certified that the conditions of competence, consent, gravity/incurability, and enduring/intolerable suffering have been met. This is, in fact, close to what is found in Quebec's Act Respecting End-of-Life Care, where patients meeting conditions similar to those defined in Carter may request medical aid in dying from a physician who must, in addition to meeting other obligations under the Act, obtain the opinion of a second independent physician before administering the necessary aid. Whatever the process, it is likely to allow variance both across and within provinces, as well as to create the possibility of delays that would have the effect of prolonging suffering. Ironically, in this situation the policy regime would be vulnerable to the same constitutional attack that succeeded in invalidating the Criminal Code's therapeutic abortion provisions in Morgentaler (1988).

The government's response to Carter was delayed, but arguably moderate. On July 17, 2015 it announced the establishment of an external panel to review options for responding to the judgment. With a requirement to report by late Fall 2015, the threeperson panel's mandate is to consult with the public and key stakeholders, especially the interveners in Carter. Although there was some criticism of the panel's composition, this response to Carter is qualitatively different from the responses to the two cases noted in the introduction and now discussed below.

If any judgments are consistent with the narrative of conflict between the Court and the CPC government they are Canada (Attorney General) v. PHS Community Services (2011), Canada (Attorney-General) v. Bedford (2013), and R. v. Nur (2015). ${ }^{39}$

39. Canada (Attorney General) v. PHS Community Services [2011] 3 S.C.R. 134; Canada (Attorney-General) v. Bedford, [2013] 3 S.C.R 1101; R. v. Nur, [2015] SCC 15. 
At issue in PHS Community Services was the constitutionality of the exercise of ministerial discretion under the 1996 Controlled Drugs and Substances Act. Section 56 of the Act granted the federal Minister of Health the authority to grant an exemption from its application to persons or controlled substances where "in the opinion of the Minister, the exemption is necessary for a medical or scientific purpose or is otherwise in the public interest." In 2003 the LIB2 minister of health granted an exemption to PHS Community Services to operate Insite, a supervised safe injection site for intravenous drug users. The purpose of the exemption was to reduce the incidence of HIV/AIDS and hepatitis $\mathrm{C}$ among this population while assisting its members to end their dependency on drugs. In 2006 and 2007 the CPC Minister granted temporary extensions to the exemption, but in 2008 the Minister announced that he had decided to deny an application to extend the original exemption.

PHS Community Services sought to preempt the Minister's denial by bringing an action before British Columbia courts, arguing that denial of the exemption would infringe rights protected under s. 7 of the Charter in a manner inconsistent with the principles of fundamental justice. ${ }^{40}$ In 2011 a unanimous Court, including two justices appointed by the CPC government, declared under the Chief Justice's name that the Minister's failure to grant an exemption violated the claimants' rights to life, liberty and security of the person and contravened the principles of fundamental justice. According to the Court, removal of the exemption infringed these rights by making it impossible for Insite clients to access the "lifesaving and health-protecting services" offered at the facility. The Court further declared that, by refusing to exercise his discretion under s. 56 of the Act, the Minister was acting in a way that caused the Act to apply arbitrarily, over broadly, and grossly disproportionately. Arbitrarily because it produced a result directly contrary to the Act's purpose by undermining rather than protecting public health and

40. There was also a division of powers challenge to the legislation, but the Court rejected it relatively summarily. 
safety; grossly disproportionately because it increased the risk of death and disease among intravenous drug users without generating any public policy benefit for Canada.

Not only was the Court unambiguous in rebuking the Minister's decision, it imposed an unusually interventionist remedy. The Court determined that the special circumstance of the case merited a writ of mandamus, which is an order for a government official to take specific action. The Court thus ordered the Minister immediately to grant the exemption under s. 56, and it further defined the Minister's ongoing constitutional obligations in exercising discretion under the Act in a way that makes it virtually impossible to deny future applications for exemptions from Insite or any other supervised injection site like it. In PHS Community Services the Court chastised the CPC government for ignoring evidence "on which successive federal Ministers have relied in granting exemption orders over almost five years, "41 and acted to protect the policy status quo from a change in government.

A similar conflict is evident in Bedford. At issue was whether criminal prohibitions against keeping or being in a "bawdy house," living on the avails of prostitution, and communicating for the purposes of prostitution infringe the constitutional right to security of the person under s.7 of the Canadian Charter of Rights and Freedoms. ${ }^{42}$ The Court unanimously held that the impugned provisions did infringe s.7 by increasing the risk that prostitutes would become victims of violence while engaging in an activity-exchanging sex for money - that is not itself prohibited. The Court further held that the infringement was inconsistent with the principles of fundamental justice because the impugned provisions were, as in PHS Community Services, arbitrary, overbroad, and grossly disproportionate to their objectives.

\section{1. [2011] 3 S.C.R. 134, para. 131}

42. This was the second time the Court had been asked to review the constitutionality of these provisions under the Charter. See Reference re ss. 193 and 195.1(1)(C) of the criminal code (Man.) [1990] 1 SCR 1123. The constitutional questions in 1990 were different, however, since they involved freedom of expression under s. 2 and liberty interests under s.7. 
Technically a criminal law case, the list of non-governmental intervenors in the case illustrates the extent to which Bedford was also a clash between differing views of social policy and moral values. Indeed, the Court recognized this in describing the regulation of prostitution as a "complex and delicate matter" 43 for which the criminal law might simply be too blunt a regulatory instrument. Although the provisions declared unconstitutional in Bedford dated back to the nineteenth century and had been endorsed by a previous government in a consolidation of the Criminal Code almost thirty years earlier, it was clear that the CPC government preferred to continue regulating prostitution through the Criminal Code.

In April 2015 the Court issued a judgment that provides perhaps the closest fit with the "fractious relationship" narrative of all of the post-2006 government losses under the Charter. At issue in R. v. Nur (2015), was the constitutionality of a five-year mandatory minimum sentence for firearm related offences that the CPC government had enacted in 2012. In a six-to-three judgment, with the Chief Justice writing for the majority, the Court held that this mandatory minimum constitutes an unjustified infringement of the right not to be subjected to cruel and unusual punishment as guaranteed by s. 12 of the Charter. However, although the majority concluded that the five-year mandatory minimum might foreseeably be grossly disproportionate if applied to other offenders, it conceded that it was not grossly disproportionate as applied to the specific offenders involved in the appeal. Consequently, the majority invalidated the provision, but upheld the sentences applied both to Nur and the other offender involved in the appeal.

In reaching her judgment, the Chief Justice concentrated on the principle of proportionality in sentencing, which she defined as "a highly individualized exercise, tailored to the gravity of the offence, the blameworthiness of the offender, and the harm

43. [2013] 3 S.C.R 1101, para. 165. 
caused by the crime." ${ }^{44}$ Mandatory minimum sentences, she argued, threaten this principle due to their emphasis on "denunciation, general deterrence, and retribution." 45 Moreover, she found only the weakest of rational connections between mandatory minimum sentences and general deterrence, although she agreed that such a connection did exist with respect to denunciation and retribution. ${ }^{46}$ Finally, imposing a mandatory minimum sentence for mere possession of firearms, rather than more closely connecting it to "conduct attracting significant moral blameworthiness," violated the principle of minimal impairment of rights. ${ }^{47}$

In many respects, given the majority's rejection of the sentencing principlesdenunciation, general deterrence, retribution-undoubtedly embraced by the CPC government, ${ }^{48} \mathrm{Nur}$ presents itself as a clear case of the Court's repudiating a recentlyenacted core policy of the government. However, even Nur is more complicated than this. The Chief Justice did not reverse the sentences in the specific cases, nor did she even declare mandatory minimum sentences unconstitutional per se (although she set a very high threshold for justifying them). Most obviously, unlike PHS Community Services, Carter, and Bedford, the Court was divided in Nur. Furthermore, the CPC government was not alone in defending the constitutionality of the mandatory minimum: Ontario defended the law as a party to the case, and British Columbia and Alberta intervened in favour of upholding its constitutionality. Finally, one of the CPC government's allies in another case involving the gun registry (discussed below) was opposed to it in this case.

Both the overall picture, and specific circumstances, of judicial invalidations under the Charter during the $\mathrm{CPC}$ government indicate a much more complex

\footnotetext{
44. R. v. Nur, [2015] SCR 15 at para. 43.

45. Ibid., para. 44.

46. Ibid., para. 115.

47. Ibid., para. 117

48. For a good analysis of the CPC government's crime agenda under the Charter, see Kent Roach, "The Charter versus the Government's Crime Agenda," Supreme Court Law Revew (2d) 58 (2012), 211-43.
} 
relationship between the Court and the government than can be captured through a simple "scorecard" of outcomes. Indeed, two of the losses that have contributed significantly to the narrative-Bedford and Carter-involved legislation passed by previous governments, as well as reversals of the position taken by the Court itself in earlier judgments. Even the CPC government's confrontational responses to PHS Community Services and Bedford were not unprecedented: neither the PC nor LIB2 governments quietly deferred to the Court in a series of losses in the area of sexual assault, for example. $^{49}$ To be sure, the book is not yet closed on the Court-CPC relationship, and future judgments — including those rendered after the CPC leaves government—-may alter the picture in a manner more consistent with the "fractious relationship" narrative. Nevertheless, this set of evidence suggests that, at least for the moment, the narrative is exaggerated.

\section{The Reference Cases}

Bedford, PHS Community Services, Carter and Nur represent the typical situation in which governments are pulled into constitutional litigation involuntarily. The same cannot be said of most reference cases, where governments seek to advance their policy agenda by extracting a favourable advisory opinion from the Court. The three occasions on which the CPC government has sought advice from the Court through the reference procedure are hybrids that combine both involuntary and purposeful elements. In each instance actions were launched, or threatened, by other parties, drawing the CPC government into a legal battle over which it sought to gain greater control by initiating its own process and framing its own questions; in each instance the tactic was

49. See the legislative responses to R. v. Seaboyer, [1991] 2 S.C.R. 577 (Bill C-49); and R. v. O'Connor, [1995] 4 S.C.R. 411 (Bill C-46); and R. v. Daviault, [1994] S.C.R. 63 (S. 33.1 of the Criminal Code, added in 1995). Roach calls the third of these an "inyour-face" response. See Kent Roach, The Supreme Court on Trial: Judicial Activism or Democratic Dialogue (Toronto: Irwin Law, 2001), 274-77. 
unsuccessful. ${ }^{50}$ In this section I examine this distinctive set of cases, which are not reflected in the aggregate data presented above on judicial invalidations under the Charter. It is with these cases where the strongest argument for a particularly conflictual Court-government relationship lies.

At issue in the Securities Act Reference (2011) was the CPC government's proposal to implement an idea dating back to at least 2003 by establishing a single national securities regulator. ${ }^{51}$ Ontario, where Canada's largest securities market is located supported the project, but Quebec, Alberta, and other provinces opposed it. The question posed to the Court under the reference procedure was whether the proposed Securities Act fell within the federal government's general legislative power to regulate trade and commerce. The federal government argued that the securities market had evolved from a provincial to a national matter, providing Parliament with legislative authority over all aspects of its regulation. ${ }^{52}$ The Court disagreed, finding that, although "aspects of the securities market are national in scope and affect the country as a whole," the proposed legislation mostly dealt with matters that had traditionally been recognized as falling within provincial legislative authority over property and civil rights within the province. ${ }^{53}$ The Court therefore answered the reference question in the negative, advising the CPC government that it could not establish a single, national scheme to regulate the securities trade under a single regulatory body.

Although the Court expressed agnosticism with respect to "whether a single national securities scheme is preferable to multiple provincial regimes," ${ }^{24}$ it did express a strong preference about how federalism should function. It urged "the federal

50. Reference re Securities Act, [2011] 3 S.C.R. 837; Reference re Supreme Court Act, ss. 5 and 6, 2014 SCC 21; Reference re Senate Reform, 2014 SCC 32.

51. See Wise Persons' Committee-Committee to Review the Structure of Securities Regulation in Canada. It's Time. Ottawa: Department of Finance, 2003.

52. [2011] 3 S.C.R. 837, para. 4.

53. Ibid., para. 6.

${ }^{5}$. Ibid., para. 10. 
government and the provinces to exercise their respective powers over securities harmoniously, in the spirit of cooperative federalism."55 Consequently, the Court refused to signal which alternative scheme might be constitutional, but it did find it appropriate to "note the growing practice of resolving the complex governance problems that arise in federations...by seeking cooperative solutions that meet the needs of the country as a whole as well as its constituent parts." According to the Court, the "federalism principle upon which Canada's constitutional framework rests" demands nothing less than that cooperation be its "animating force.",57

The Securities Act Reference can thus be read as much as an implicit critique of the CPC government's style of intergovernmental relations as a repudiation of its preferred policy for regulating securities markets. ${ }^{58}$ Indeed, although there have been numerous federal-provincial-territorial meetings held since 2006, the CPC government has been notable for the absence of First Ministers' meetings, holding only two during its term in power, and none since 2009. Unlike PHS Community Services, where the Court had a strong opinion about the CPC government's policy, it was largely indifferent to the substance of the proposal under review in the Securities Act Reference, but clearly deeply concerned with how the federal government proposed to substitute a national regulatory regime for the existing local regimes. To be fair, it is arguable that this concern also extended to the provinces that intervened in the reference: the Court's message to both was cooperation rather than confrontation.

\footnotetext{
55. Ibid., para. 9 ,

56. Ibid., para. 132.

57. Ibid., para. 133.

58 . Others have noted that the opinion provides an interesting commentary on the Court's understanding of the nature of Canadian federalism. See Gordon DiGiacomo, "The Supreme Court of Canada's Federalism as Expressed in the Securities Reference," Institute of Intergovernmental Relations, School of Policy Studies, Queen's University, Working Paper 2012-01.
} 
If the level of conflict was relatively mild in the Securities Act Reference, the same cannot be said for the Supreme Court Act Reference or the Senate Reference. At issue in the former was the eligibility of Federal Court judges for appointment to one of the three seats reserved for Quebec on the Supreme Court. On September 30, 2013 the Prime Minister announced the nomination of Justice Marc Nadon, a supernumerary (semi-retired) judge of the Federal Court of Appeal, to fill the Quebec seat vacated by the retirement of Justice Morris Fish. First called to the Barreau du Québec in 1974, Nadon practiced for almost twenty years in Québec before being named to the trial division of the Federal Court by the PC government in 1993, from which he was elevated to the appellate division in 2001. Upon his appointment, Nadon ceased to be a member of the Québec bar. As a Federal Court judge without current membership in the Québec bar, Nadon's eligibility for appointment to one of the Quebec seats was uncertain.

The CPC government recognized the unconventionality of the appointment and sought expert opinions on Nadon's eligibility for appointment from two former Supreme Court justices (Ian Binnie and Louise Charron), as well as from one of Canada's most respected and distinguished constitutionalists (Peter Hogg). All three delivered a positive assessment of eligibility, and the formal process of appointment began on October 2, 2013. Five days later, Chief Justice Beverley McLachlin swore Justice Nadon in as a member of the Court, but on the same day a Toronto lawyer launched a challenge to the appointment's legality in the Federal Court. One day later, Justice Nadon announced he would not participate in any Supreme Court proceedings while this challenge was underway. On October 17, Quebec also announced that it would contest the appointment. On October 22, the CPC government's omnibus budget bill included amendments to the Supreme Court Act to clarify that Federal Court judges appointed from Quebec are 
eligible to fill Quebec vacancies, and it sent a reference to the Supreme Court regarding the constitutionality of these amendments and Nadon's appointment itself. ${ }^{59}$

The Court heard oral argument in the Supreme Court Reference on January 15, and delivered its judgment on March 21. In its 6-1 decision, the Court answered both questions posed to it by the CPC government in the negative, rejecting both the government's interpretation of the Supreme Court Act and its assertion of legislative authority to amend the act to make it clear that former members of the bar, including the Quebec bar, are eligible for appointment. ${ }^{60}$ At issue on the first question was the relationship between ss. 5 and 6 of the Supreme Court Act. Section 5 specifies the requirement that anyone can be appointed to the Court who is or has been a member of a provincial superior court or a member of a provincial bar for at least ten years; section 6 specifies that at least three of the Court's judges "shall be appointed from among the judges of the Court of Appeal or of the Superior Court of the Province of Quebec or from among the advocates of that Province." The Court determined that s.5 established a minimal threshold for eligibility and that s. 6 created an additional requirement of current membership for eligibility for the Quebec seats. Consequently, although s.6 did not specify a minimum length of membership in the Québec bar, the majority held that the threshold of ten years membership established in s.5 also applies to the Québec seats.

59. One of the unanswered questions about this sequence of events is why Justice Nadon voluntarily abstained from taking up the position to which he had been duly sworn, or why the government took the legislative and legal action it did. One can imagine a scenario in which Justice Nadon took his seat on the Court and began hearing, and deciding, cases during the period that both the private and reference challenges to his appointment worked their way through the judicial system. In this circumstance, judicial invalidation of his appointment would have thrown into doubt the results of any case in which he had participated. With this possibility in mind, would any court have been willing to invalidate the appointment?

60. Justice Moldaver dissented. He agreed with the CPC government's interpretation of sections 5 and 6 and therefore found it unnecessary to decide whether the amendments were legitimate (as they were redundant given his answer to the first question). 
The Court thus declared that Federal Court judges like Justice Nadon are ineligible for appointment to one of the Court's Québec seats.

This result was a clear defeat for the CPC government, but it is perhaps the Court's treatment of the second reference question that is more important. The government passed amendments to both sections 5 and 6 designed to clarify that past membership in a provincial bar for ten years, including for the Québec seats, satisfied the eligibility requirement. ${ }^{61}$ The question here was whether Parliament could effect this change through ordinary statute, or whether it required a constitutional amendment. The Constitution Act, 1867 did not establish the constitutional requirement for a general court of appeal for Canada, it only established Parliament's authority to create such an institution. However, despite not changing this feature of the 1867 constitution, the Constitution Act, 1982 included the Court's composition and other essential features as matters covered by the unanimity and 7/50 rules, respectively, for amending the constitution. ${ }^{62}$ The Court took the view that the amendments to ss. 5 and 6 of the Supreme Court Act affected the Court's composition and could therefore only be achieved through a constitutional amendment ratified unanimously by the federal and provincial governments.

The Court thus took advantage of this unexpected opportunity to confer upon itself a constitutional status it had never before enjoyed. If neither its composition nor other essential features can be changed except by constitutional amendment, then the existence of a general court of appeal for Canada is no longer a Parliamentary option, as anticipated by s.101 of the Constitution Act, 1867, but a constitutional necessity. The

61. There was some ambiguity in s.5, which recognized past membership on a superior court more explicitly than past membership of a provincial bar. The clarifying amendment for s.5 was ultimately unnecessary, as the Court resolved this ambiguity in favour of past membership in both sets of institutions.

62 . The $7 / 50$ formula stipulates that amendments may be enacted through resolutions of the Senate and House of Commons and the legislative assemblies of two-thirds of the provinces representing at least 50 percent of the population. 
outcome in the Supreme Court Act Reference both blocked an action important to the CPC government and served the Court's long-term institutional interests. In this sense, the Supreme Court Reference represents a perfect strategic victory for the Court relative to the government: it maximized both its short-term policy interest in influencing appointments to the Court and its long-term institutional power and prestige. Perhaps no case better illustrates the Court's status as a political rather than legal institution. ${ }^{63}$

Slightly more than a month later the Court issued its unanimous opinion in the Senate Reference. The CPC government launched this reference after Quebec announced that it was submitting a reference to the Quebec Court of Appeal concerning Bill C-7, through which the CPC government hoped to achieve certain reforms to the Senate. ${ }^{64}$ The bill proposed to reform the Senate in two ways: (1) by providing an electoral framework, adopted by provinces and territories at their own discretion, to generate a list of nominees that must be considered by the Prime Minister in recommending Senate nominees to the Governor General; and (2) by changing the tenure of Senators to a single, nonrenewable fixed term of nine years. The government asserted that the first reform could be achieved through ordinary legislation, but recognized that the second required an amendment to s. 29 (2) of the Constitution Act, 1867. However, the government further asserted that this constitutional change fell within the unilateral amending authority of Parliament under s. 44 of the Constitution Act, $1982 .{ }^{65}$

63. I have discussed this characteristic of the Court, and its strategic relationship to governments, in "Strategic Judicial Behaviour and The Canadian Charter of Rights and Freedoms," in Patrick James, Donald Abelson and Michael Lusztig, eds. The Myth of the Sacred: The Charter, the Courts and the Politics of the Constitution in Canada, (Montreal and Kingston: McGill-Queen's University Press, 2002): 147-67.

64. Readers should note that I prepared an expert opinion for the Government of Canada in the Quebec reference case, which Canada also filed as part of its evidence in the Supreme Court reference.

65. This path to constitutional amendment applies to matters relating to executive government of Canada or the Senate and House of Commons. 
Three principal objections were raised to Bill C-7: (1) that it would undermine the Senate's independence; (2) that it would change the method of selecting senators by transferring authority from the Prime Minister to the electorate; and (3) that it would affect the Senate's powers by fundamentally altering its essential representational characteristics. According to this argument, these aspects of Bill C-7 would, in the aggregate, have profound effects on the fundamental features or essential characteristics of the Senate. Consequently, all of the changes contained in the Bill required constitutional amendment according to the more stringent rules of unanimity or the $7 / 50$ formula. The reference questions posed by Quebec to its Court of Appeal were specifically directed to Bill C-7, and in October of 2013 the Quebec Court held that it could only be enacted through constitutional amendment according to the 7/50 amending rule. The Supreme Court Senate Reference, for which oral arguments took place in November 2013, dealt with a more extensive set of questions that went beyond the specific provisions of Bill C-7, including questions about how the Senate might be abolished. Like the Quebec court, the Supreme Court held that most of the proposed changes to the Senate could only be achieved through the $7 / 50$ procedure, and that abolition would require the unanimous consent of the provinces. Only the net worth eligibility requirement for appointment could be enacted through the federal government's unilateral amending power.

The Court reached this opinion largely on the grounds that the Constitution should be understood as a comprehensive structure, with a particular architecture that was greater than the sum of its "discrete textual provisions." 66 In the Court's view, consultative elections would fundamentally change the Constitution's architecture, and thus required approval through the $7 / 50$ amending formula. ${ }^{67}$ Similarly, the Court characterized the Senate as a core element of this architecture, and that changes to

$\begin{array}{ll}66 & 2014 \text { SCC 32, para. } 27 . \\ 67 & \text { Ibid., paras. 54-67. }\end{array}$ 
senatorial tenure affected the fundamental nature of this core element. Consequently, this change engaged the interests of the provinces and could not be achieved without their consent. $^{68}$

The Supreme Court Reference and the Senate Reference both negated initiatives of high importance to the CPC government, although the impact of the second will endure longer. While the government failed to appoint its first choice to the Court, by early June 2014 it had named a replacement for Justice Nadon (Justice Clement Gascon), and six months later it made a second appointment, Suzanne Coté, from the ranks of the Quebec bar. Senate reform now appears to have fallen very low on the government's agenda, and the Prime Minister simply ceased to recommend appointments to the upper house. ${ }^{69}$ Not surprisingly, the absence of action in filling vacant seats has become the subject of litigation filed in the Federal Court, setting up the potential for another direct confrontation between the government and the Supreme Court. ${ }^{70}$

68. Ibid., paras. 71-83. This is not the place to engage in a full-scale analysis of the Court's conceptual, historical, and empirical reasoning in the Senate Reference. My research and conclusion on these matters can be found in Christopher Manfredi, "Expert Opinion on the Possible Effects of Bill C-7, An Act respecting the election of Senators and amending the Constitution Act, 1867 in respect of Senate term limits," June 2013 (filed by the Government of Canada in the Québec Court of Appeal and the Supreme Court of Canada). One thing worth noting is the Court's relative lack of engagement with the numerous expert reports submitted by both sides in the proceedings. To be sure, the Court cited several scholarly studies of the Senate and the amending procedure, but only two of those studies spoke directly to the substance of Bill C-7. Perhaps the Court determined that the content of those expert reports was adequately communicated in the parties' facta and oral arguments.

69 . In late July 2015 the Prime Minister announced a moratorium on Senate appointments. See Steven Chase, "Stephen Harper vows not to make any Senate appointments," Globe and Mail (July 24, 2015), http://www.theglobeandmail.com/news/politics/harper-wall-to-call-for-abolition-ofsenate-on-friday-report/article25658737/ (accessed 18 August 2015).

70 Alani v. The Prime Minister, the Governor General, and the Queen's Privy Council for Canada (Federal Court, Trial Division, T-2506-14). Readers should note that I prepared an expert opinion in this case for the Government of Canada. 


\section{Aboriginal Title and the Gun Registry}

Among the judgments frequently cited in support of the narrative that the CPC government is facing a particularly oppositional Supreme Court is Tsilhqot'in Nation v. British Columbia (2014). ${ }^{71}$ At issue was the Tsilhqot'in First Nation's claim to aboriginal title over an area of central British Columbia. In another unanimous judgment authored by the Chief Justice, the Court clarified its existing jurisprudence under s. 35 of the Constitution Act, 1982 and found that Aboriginal title "flows from occupation in the sense of regular and exclusive use of land"; that Aboriginal title "confers the right to use and control the land and to reap the benefits flowing from it"; and that, once established, Aboriginal title prohibits Crown incursions on the land without the consent of the Aboriginal group holding the title. ${ }^{72}$ In this instance the Court found that the Tsilhqot'in First Nation did indeed possess Aboriginal title, and that British Columbia had acted in a manner inconsistent with its obligations to the Tsilhqot'in.

From the perspective of the CPC government, the Tsilhqot'in judgment established an obviously unwanted obstacle to its objective of authorizing the Northern Gateway pipeline to transport oil from Alberta to the British Columbia coast. Beyond that, however, it is difficult to characterize the judgment as specifically targeting the CPC government. To begin with, the primary target of the Tsilhqot'in Nation's original claim was the government of British Columbia; the government of Canada was a secondary respondent. Second, the litigation that eventually produced the judgment began in 2002, during the LIB2 government, and involved a 339-day trial spread over five years. The Tsilhqot'in won a partial victory at trial, which the BC Court of Appeal reversed. The Tsilhqot'in people were thus appealing that loss to the Supreme Court; this was not a case of an intransigent government seeking to reverse rights unambiguously granted throughout lower court proceedings. Finally, to accept Tsilhqot'in as a judgment

71. Tsilhqot'in Nation v. British Columbia, [2014] 2 S.C.R. 257.

72. Ibid., para. 2. 
especially targeted against the CPC government, it is necessary that one or both of two counterfactuals be true. First, that another government would have conceded the case or defended Crown title and regulatory authority less vigorously; or second, that the Court would have reached a different conclusion had the CPC government not been in power. Although the Court was undoubtedly aware of the political and policy context of the dispute, there is little evidence that the CPC government fared worse in Tsilhqot'in than would have another government. ${ }^{73}$

The "CPC government v. the Court" narrative is further blunted by an important federalism decision in March 2015: Québec (Attorney General) v. Canada (Attorney General) (2015). ${ }^{74}$ At issue was the constitutionality of a key element of the CPC government's removal of long gun registration requirements. The long-gun registry had been an integral part of the 1995 LIB2 government's Firearms Act, and its abolition was a key element of the CPC's policy platform. In 2012, shortly after winning a majority, the CPC government enacted the Ending the Long-gun Registry Act, which repealed the registry requirement for long guns, decriminalized the possession of unregistered long guns, and required the destruction of all records contained in the registry with respect to long guns. ${ }^{75}$ Québec, which intended to establish its own registry, sought to prevent destruction of the data connected to the province. Québec prevailed in the Superior Court, lost in the Québec Court of Appeal, and appealed to the Supreme Court. Its argument was that the concept of "cooperative federalism" limited the exercise of the federal Parliament's exclusive constitutional jurisdiction.

The decision was a narrow one-five-to-four_but the majority judgment, which included the Chief Justice in this instance, found destruction of the data both within

73. It might also be noted that, in 2011, the Court unanimously rejected an Aboriginal title claim in Lax Kw'alaams Indian Band v. Canada (Attorney General), [2011] 3 S.C.R. 535.

74. Québec (Attorney General) v. Canada (Attorney General), [2015] SCC 14.

75. S.C. 2012 , c. 6. 
Parliament's constitutional authority over criminal law and unaffected by the principle of cooperative federalism. Finding that the data's existence flowed exclusively from the federal Parliament's criminal law power, and that the principle of cooperative federalism cannot limit the scope of that power, the majority upheld the Québec Court of Appeal's decision that Québec had no right to the data. ${ }^{76}$ Like Nur (discussed above), the gun registry case brought the Court into direct contact with the CPC government's legislative agenda. That the Court, however narrowly, deferred to that agenda in this instance suggests a more nuanced approach to understanding the Court-government relationship. Indeed, of the 18 total votes cast in these two judgments (Nur, gun registry case) from the spring of 2015, 8 were cast in favour of the government while 10 went against it. This suggests neither strong affirmation nor repudiation of the CPC government's agenda. ${ }^{77}$

\section{Conclusion}

The purpose of this article has been to bring greater analytical rigour to a narrative, common among both popular and academic commentaries, that there is a particularly antagonistic relationship between the CPC government and the Supreme Court. The narrative stems from a series of high profile losses by the government in constitutional cases, as well as the Government's and Prime Minister's reaction to those decisions. In some versions of the narrative, these losses suggest that the Court has become an explicitly, and even self-consciously, oppositional force against the CPC government's "extremist" policies. In other versions of the narrative, especially in the aftermath of the

76. [2015] SCC 14, at para. 23-25.

77. However, it is intriguing that the majority judgment in the gun registry case takes up only 46 of the complete 203-paragraph judgment, and that the dissent is much more detailed with respect to background and lower court proceedings. This often indicates, especially in 5-to-4 outcomes, that a dissent began as the majority judgment, but lost the support of at least one justice along the way. See Peter McCormick, "Standing Apart: Separate Concurrence and the Modern Supreme Court of Canada, 1984-2006," McGill Law Journal 53 (2008), 148. This, in turn, raises the possibility of strategic deference. 
Nadon appointment controversy, it is a personal conflict between the Prime Minister and the Chief Justice. ${ }^{78}$

In order to explore this narrative analytically, the article closely examined three types of cases: instances of judicial invalidation under the Charter, key reference opinions, and two cases involving Aboriginal rights and the gun registry. One key finding is that it is difficult to draw a direct line from losses in Charter cases to any particular relationship between the government and the Court. In 73 percent of the CPC's Charter losses, the policy invalidated by the Court belonged to a predecessor government. Indeed, as defender or enactor, the CPC's record in Charter cases has not differed significantly from that of the two other post-Charter governments. Even the Tsilhqot'in Nation judgment is not necessarily a clear strike against the CPC government: British Columbia was the principal respondent, and the LIB2 government was initially responsible for making the federal argument against title in the case. By contrast, the three reference cases initiated by the CPC government offer a clearer portrait of confrontation, since in all three cases the Court blocked initiatives considered important by the government. However, the Court provided a clear, if narrow, victory to the CPC government in the gun registry case.

Like all analyses, this one has limitations. The most obvious limitation, referred to earlier in the article, is that the book is not yet closed on judicial review of CPC government legislation and policy. Over time, the variation between the CPC government's experience in the Court and that of prior governments may yet widen. A second limitation is that the article has not attempted to examine whether the CPC government significantly changed litigation strategies and arguments in the cases it

78. There is some irony in this, given that there was at least one moment, in 2004, when Beverley McLachlin and Stephen Harper were of the same mind on an important constitutional issue. In Harper v. Canada (Attorney General), [2004] 1 S.C.R. 827 the Chief Justice wrote a dissenting judgment that essentially agreed with the position advocated by Harper with respect to third-party election advertising. 
inherited from previous governments. This is an interesting avenue for further research, but it would also require undertaking an overall evaluation of how all governments approach inherited litigation to determine whether one government's approach is unique in some way.

Perhaps the most interesting development since 2006 is the adoption of a more consistently confrontational approach by the CPC government in its legislative responses compared to its predecessors. This has occurred even in cases like PHS Community Services and Bedford, where the invalidated legislation or policy did not originate with the CPC government. Although other governments also refused to defer completely to the Court in certain areas, it may be emerging as the norm under the CPC government. In this sense, the CPC government may be asserting an equal authority to interpret the Constitution's meaning that could bring it into much sharper conflict with the Court. 